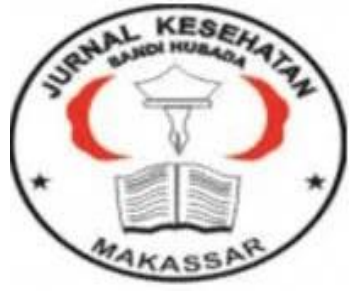

Jurnal Ilmiah Kesehatan Sandi Husada

hhttps://akper-sandikarsa.e-journal.id/JIKSH

Volume 9, Nomor 2, Desember 2020, pp 933-939

p-ISSN: 2354-6093 dan e-ISSN: 2654-4563

DOI: $10.35816 /$ jiskh.v10i2.434

\title{
Pola Kepekaan Bakteri Terhadap Antibiotik pada Pasien Rhinosinusitis
}

Sensitivity Pattern of Bacteria to Antibiotics in Rhinosinusitis Patients

\section{Hasna Laili Jovita}

Pendidikan Dokter, Universitas Lampung

\section{Artikel info}

\section{Artikel history:}

Received; Juli 2020

Revised: Agustus 2020

Accepted; September 2020

\begin{abstract}
Abstrak
Latar Belakanng: rhinosinusitis adalah peradangan yang mengenai hidung dan sinus paranasal. Salah satu pengobatan secara medikamentosa yaitu dengan antibiotic. Penggunaan antibiotic tidak rasional menimbulkan permasalahan yang berkembang yaitu resistensi bakteri dan komplikasi. Tujuan: Mengetahui pola kepekaan bakteri terhadap antibiotic pada pasien rhinosinusitis. Metode: menggunakan studi literatur dengan menelaah berbagai jurnal nasional maupun internasional, membandingkan dan menyatukan hasil temuan dari penelitian yang disajikan dalam artikel. Hasil: penentuan antibiotic sebagai penatalaksanaan medikamentosa pada rhinosinusitis harus sesuai dan memberikan efektifitas yang maksimal untuk kesembuhan. Kesimpulan: terdapat beberapa hasil pola kepekaan bakteri terhadap antibiotic sesuai bakteri penyebab rhinosinusitis.
\end{abstract}

\begin{abstract}
Background: rhinosinusitis is an inflammation affecting the nose and paranasal sinuses. One of the medical treatments is with antibiotics. The irrational use of antibiotics creates problems, namely bacterial resistance and complications. Objective: To determine the pattern of bacterial sensitivity to antibiotivs in rhinosinusitis patient. Methods: using literature studies by examining various national and international journals, comparing and combining the findings of the research presented in the article. Result: the determination of antibiotics as medical treatment in rhinosinusitis must be appropriate and provide maximum effectiveness for healing. Conclusion: there are several the pattern of bacterial sensitivity to antibiotics according to the bacteria that cause rhinosinusitis.
\end{abstract}


Keywords:

Rhinosinusitis;

Uji Kepekaan;

Antibiotik;
Coresponden author:

Email: hasnajovita@gmail.com

artikel dengan akses terbuka dibawah lisensi CC BY -4.0

\section{Pendahuluan}

Rhinosinusitis merupakan masalah kesehatan global yang signifikan sebagai cermin dari peningkatan frekuensi rhinitis alergi yang ditandai adanya peradangan simtomatis pada sinus paranasales dan cavum nasi dan berakibat dalam beban biaya kesehatan yang besar, penurunan kualitas hidup, produktivitas kerja, serta daya konsentrasi bekerja dan belajar masyarakat. Rhinosinusitis dibagi menjadi dua berdasarkan durasinya yaitu akut dan kronis (Rosenfeld., 2015). Menurut European Position Paper on Rhinosinusitis and Nasal Polyps (EP3OS) 2012, rhinosinusitis adalah peradangan yang mengenai hidung dan sinus paranasal (Fokkens, W. J., 2012).

Onset perjalanan penyakit rinosinusitis terdiri dari akut dan kronik, dimana akut yaitu perjalanan penyakit kurang dari 12 minggu, sedangkan kronik perjalanan penyakit lebih dari 12 minggu (Zhang Y., 2017). Rinosinusitis akut tanpa terapi adekuat akan jatuh pada keadaan kronik dan memperpanjang 2 masa pengobatan. Rinosinusitis kronik bila tidak ditangani dengan tepat dapat menyebabkan timbulnya beberapa komplikasi berupa infeksi pada orbita, infeksi intrakanial seperti meningitis akut, mukokel atau kista, osteomielitis, dan abses subperiosteal. Prevalensi rinosinusitis kronik pada seluruh populasi dunia adalah sekitar $10-12 \%$, mayoritas penderitanya mengalami gejala sedang sampai berat (Massoth, L., Anderson, C., \& McKinney, 2019). Sinusitis kronik merupakan salah satu penyakit kronis dengan prevalensi tinggi di Amerika Serikat yang memengaruhi semua kelompok umur. Prevalensinya sekitar 146 per 100 populasi dan insidensinya akan terus meningkat tiap tahun (Bubun J., Azis A., Akil A. \& F., 2009). Angka kejadian rinosinusitis kronik di Indonesia belum diketahui dengan pasti. Menurut Depkes RI tahun 2003, penyakit ini berada pada urutan ke 25 dari 50 pola penyakit peringkat utama atau sekitar 102.817 pasien yang dirawat di rumah sakit (Yama D, P. K., Setiawan, E. P., \& Sutanegara, 2018).

Pada penelitian di Thailand, dari 154 pasien anak-anak yang didiagnosis rinosinusitis, 103 anak diantaranya merupakan rinosinusitis akut dan 51 anak menderita rinosinusitis kronis. Penderita dengan rinitis alergi mempunyai resiko lebih besar berkembang menjadi rinosinusitis kronis (Poanchanukoon 0, 2012). Pada tahun 2015 sebanyak $64 \%$ dari pasien rinitis alergi yang mengunjungi departemen otolaringologi - kepala dan bedah leher di Rumah Sakit Hasan Sadikin Bandung (Fauzi., Sudiro M., 2015). Rinosinusitis kronik merupakan salah satu penyakit yang sering dijumpai di poli THT RSUD A. Dadi Tjokrodipo. Didapatkan data sebanyak 84 orang yang terdiagnosa rhinosinusitis kronik tahun 2016 dan tahun 2017 sebanyak 45 orang (Y Nurmalasari., 2017). Pada penelitian terdahulu yang dilakukan di Universitas Gadjah Mada, didapatkan hasil bahwa pada penderita rhinosinusitis kronis, jenis bakteri yang paling banyak tumbuh pada cavum nasi dan sinus maksila adalah Staphylococcus epidermis $(21,7 \%)$, Staphylococcus aureus $(18,3 \%)$, Klebsiella pneumonia $(13,3 \%)$, dan Pseudomonas aeruginosa $(10,0 \%)$. Bakteri terbanyak pada cavum nasi adalah Staphylococcus aureus dan pada sinus maksila adalah Staphylococcus epidermis (Saputra A., Qamariah N., 2016). Penatalaksanaan rinosinusitis kronik dilakukan untuk menghilangkan keluhan serta mencegah komplikasi dan rekurensi (Mangunkusumo E., 2016). Penatalaksanaan rinosinusitis juga dilakukan untuk mengembalikan fungsi drainase dan ventilasi ostium sinus dengan membuka sumbatan di 
kompleks osteo-meatal (KOM) sehingga drainase dan ventilasi sinus-sinus pulih secara alami dan dapat kembali pada kondisi normal rongga hidung, serta mengatasi infeksi. Tujuan terapi yaitu mempercepat penyembuhan, mencegah komplikasi, dan mencegah perubahan menjadi kronik. Pengobatan harus berupa terapi infeksi dan faktor-faktor penyebab infeksi secara bersamaan. Penatalaksanaan medikamentosa dapat berupa pemberian antibiotik, dekongestan nasal, dan antihistamin. Pungsi dan irigasi dapat dilakukan untuk mengeluarkan sekret pada sinus. Terapi pemberian antibiotik harus berkhasiat, efektif biaya, dan menghasilkan efek samping yang minimal. Oleh karenanya penentuan antibiotic yang diberikan untuk penderita rhinosinusitis harus sesuai dan memberikan efektivitas maksimal untuk kesembuhan pasien.

Permasalahan resistensi bakteri juga telah menjadi masalah yang berkembang di seluruh dunia sehingga WHO mengeluarkan pernyataan mengenai pentingnya mengkaji aktorfaktor yang terkait dengan masalah tersebut dan strategi untuk mengendalikan kejadian resistensi. Menurut WHO tahun 2002 Salah satu cara untuk mengendalikan resistensi adalah dengan penggunaan antibiotik secara rasional (Ketut Surya, 2014).

Resistensi antibiotik terhadap mikroba menimbulkan beberapa konsekuensi yang fatal. Penyakit infeksi yang disebabkan oleh bakteri yang gagal berespon terhadap pengobatan mengakibatkan perpanjangan penyakit (prolonged illness), meningkatnya resiko kematian (greater risk of death) dan semakin lamanya masa rawat inap di rumah sakit (length of stay). Ketika respon terhadap pengobatan menjadi lambat bahkan gagal, pasien menjadi infeksius untuk beberapa waktu yang lama (carrier). Hal ini memberikan peluang yang lebih besar bagi galur resisten untuk menyebar kepada orang lain. Kemudahan transportasi dan globalisasi sangat memudahkan penyebaran bakteri resisten antar daerah, negara, bahkan lintas benua. Semua hal tersebut pada akhirnya meningkatkan jumlah orang yang terinfeksi dalam komunitas (Deshpande JD., 2011)

Untuk mendapat jenis antibiotic yang sesuai dengan bakteri penyebab rhinosinusitis kronik, perlu dilakukan uji kepekaan terhadap berbagai antibiotik. Jenis bakteri yang bervariasi tersebut menyulitkan dalam pemberian antibiotik secara empiris tanpa ada uji klinis. Bakteri penyebab rhinosinusitis kronis adalah bakteri aerob dan anaerob. Beberapa bakteri yang ditemukan adalah Haemophilus influenzae, Streptococcus pneumoniae, Moraxella catarrhalis, Pseudomonas aeruginosa, ahemolytic streptococci, dan Staphilococcus aureus (Araujo E., Dall C. \& Pereira A., 2017). Penelitian dengan kultur, diagnostik molekul dan deteksi biofilm pada tahun 2013 ditemukan kuman yang terbanyak adalah Staphylococcus aureus dan Streptococcus epidermidis. Beberapa bakteri yang jarang ditemukan yaitu seperti bakteri Corynebacterium pseudodiphthericum, Moraxella catarrhalis, Streptococcus pneumonia dan Pseudomonas aeruginosa (Boase S., 2013).

\section{Metode}

Metode penelitian yang digunakan adalah studi literatur dengan menelaah berbagai jurnal nasional maupun internasional, metode ini digunakan untuk meringkas suatu topik berfungsi agar meningkatkan pemahaman terkini. Studi literatur dilakukan dengan menyajikan ulang materi yang diterbitkan sebelumnya, membandingkan, memberi pandangan dan menyatukan hasil-hasil temuan dari penelitian yang dilakukan dengan hasil-hasil temuan dari literatur-literatur terdahulu dan melaporkan fakta. Landasan teori, tinjauan teori dan tinjauan pustaka merupakan beberapa cara untuk melakukan studi literatur. Tinjauan literatur menentukan berbagai persamaan dan perbedaan berbagai hasil temuan serta memberikan ringkasan berupa publikasi terbaik dan paling relevan 
yang disajikan dalam artikel.

\section{Hasil Dan Pembahasan}

Berdasarkan penelitian yang dilakukan oleh Saputra A., Qamariah N., (2016). Dari 12 sampel penderita rhinosinusitis kronis tersebut didapatkan 6 sampel mengandung bakteri Staphylococcus aureus, 4 sampel mengandung bakteri Staphylococcus epidermidis, 1 sampel mengandung bakteri Eschirechia coli, dan 1 sampel mengandung bakteri Bacillus sp. Pada penelitian yang dilakukan oleh Harahap NIK., Siregar SM., (2018). Dari 26 sampel penderita rhinosinusitis kronis tersebut dapat terlihat jenis bakteri terbanyak adalah Staphylococcus aureus terdapat pada 9 sampel $(34,6 \%)$, Proteus sp sebanyak 6 sampel $(23,1 \%)$, Streptococcus sp sebanyak 4 sampel $(15,4 \%)$, Klebsiella pneumoniae pada 3 sampel $(11,5 \%)$ dan yang paling sedikit adalah Staphyloccus albus dan Staphylococcus sp yaitu sebanyak 2 sampel $(7,7 \%)$.

Hasil penelitian yang dilakukan oleh Dlugaszewska J., Lenkowski M., \& Pastusiak T., (2016). Bakteri yang banyak dijumpai adalah Staphylococcus epidermidis sebanyak 23 sampel $(37,1 \%)$ dari 62 sampel. Staphylococcus aureus juga berkomensal di rongga mulut dalam jumlah yang banyak. Staphylococcus aureus akan berubah menjadi patogen dan menyebabkan infeksi dipengaruhi oleh jumlah, perubahan lingkungan atau perubahan gaya hidup seperti merokok (Tiara Y., Alwi M., 2014). Hasil uji kepekaan antibiotic menunjukkan bahwa bakteri Staphylococcus aureus memiliki tingkat sensitivitas yang sama terhadap keempat antibiotik yakni sefuroksim, sefiksim, siprofloksasnm dan klindamisin sebesar $(66,6 \%)$. Sedangkan pada antibiotik amoksisilin klavulanat tingkat sensitivitasnya hanya sebesar (50\%).

Pada bakteri Staphylococcus epidermidis memperlihatkan tingkat sensitivitas yang sangat tinggi terhadap antibiotik sefuroksim dan klindamisin (100\%), diikuti dengan sefiksim (50\%), lalu amoksisilin klavulanat dan siprofloksasin (25\%). Pada bakteri Eschirechia coli menunjukkan tingkat sensitivitas paling tinggi terhadap antibiotik amoksisilin klavulanat dan sefiksim (100\%), dan sama sekali tidak menunjukkan sensitivitas terhadap ketiga antibiotik lainnya yakni sefuroksim, siprofloksasin dan klindamisin (0\%). Sedangkan pada bakteri Bacillus sp. menunjukkan tingkat sensitivitas paling tinggi terhadap sefuroksim, siprofloksasin dan klindamisin (100\%), dan sama sekali tidak menunjukkan sensitivitas pada kedua antibiotik lainnya yakni amoksisilin klavulanat dan sefiksim (Saputra A., Qamariah N., 2016). Dalam penelitian ini didapatkan bahwa sefuroksim dan klindamisin memiliki tingkat efektivitas yang sama dalam mengatasi bakteri penyebab rhinosinusitis kronis dan menempati urutan pertama diantara 5 antibiotik terpilih yang di uji coba, dengan hasil sebesar $66,6 \%$ pada bakteri Staphylococcus aureus, 100\% pada bakteri Staphylococcus epidermidis, $100 \%$ pada bakteri Bacillus sp., namun pada bakteri Eschericia coli hanya didapatkan hasil yang intermediet (100\%) terhadap sefuroksim dan klindamisin. Penelitian ini memiliki perbedaan dengan penelitian Putra NP yang mendapatkan hasil bahwa antibiotik siprofloksasin menempati urutan pertama pada uji sensitivitas antibiotik pada bakteri rhinosinusitis kronis di RSUP Dr, Sardjito pada tahun 2015 (Putra NP, 2015). 
Antibiotik sefiksim menunjukkan tingkat sensitivitas paling tinggi terhadap bakteri Eschirechia coli (100\%) dan memberikan hasil yang cukup baik pada bakteri Staphylococcus aureus $(66,6 \%)$ dan Staphylococcus epidermidis (50\%). Namun pada bakteri jenis Bacillus sp., sefiksim hanya memberikan hasil yang intermediet (100\%) Antibiotik siprofloksasin menunjukkan tingkat sensitivitas paling tinggi terhadap bakteri Bacillus sp. (100\%) dan memberikan hasil yang cukup baik pada bakteri Staphylococcus aureus (66,6\%) dan Staphylococcus epidermidis (25\%). Namun siprofloksasin memberikan hasil yang resisten terhadap bakteri Eschirechia coli (100\%). Berdasarkan penelitian yang dilakukan oleh Putra NP mendapatkan hasil bahwa siprofloksasin memiliki sensitivitas paling tinggi terhadap bakteri penyebab rhinosinusitis kronis yaitu sebesar (66,7\%) (Putra NP, 2015).

Sedangkan penelitian yang dilakukan menggunakan Antibiotik amoksisilin klavulanat menunjukkan tingkat sensitivitas tertinggi pada bakteri Eschirechia coli (100\%) dan memberikan hasil yang cukup baik pada bakteri Staphylococcus aureus (50\%) dan Staphylococcus epidermidis (25\%). Namun pada bakteri jenis Bacillus sp., amoksisilin klavulanat hanya memberikan hasil yang intermediet (100\%). Dalam penelitian tersebut diperoleh hasil resistensi antibiotic terhadap bakteri Staphylococcus aureus terhadap amoksisilin klavulanat $(33,3 \%)$ dan sefiksim $(33,3 \%)$, Lalu resistensi antibiotik pada bakteri Staphylococcus epidermidis terhadap amoksisilin klavulanat (25\%) dan siprofloksasin (25\%), kemudian resistensi antibiotik pada bakteri Eschirechia coli terhadap siprofloksasin (100\%).

Penelitian tersebut menunjukan hasil resistensi amoksisilin klavulanat terhadap Staphylococcus aureus (33,3\%) dan Staphylococcus epidermidis (25\%) menunjukkan gambaran bahwa amoksisilin klavulanat memiliki tingkat resistensi yang tinggi. Hal tersebut dikarenakan amoksisilin klavulanat memang sering menjadi pilihan utama dalam pengobatan rhinosinusitis kronis khususnya dan terapi infeksi di bidang penyakit THT pada umumnya sehingga meningkatkan kemungkinan bermutasinya kuman (Niel, 2006).

Hasil resistensi terhadap antibiotik siprofloksasim terhadap bakteri Staphylococcus epidermidis (25\%) dan Eschirechia coli (100\%) dapat dikarenakan 3 mekanisme yang sering menyebabkan resistensi pada obat golongan fluorokoinulon seperti siprofloksasim. 3 mekanisme yang terjadi yaitu : 1) Mutasi yang menyebabkan giras kuman berubah sehingga tidak dapat diduduki molekul obat lagi, 2) Perubahan pada permukaan sel kuman yang mempersulit penetrasi obat ke dalam sel, dan 3) Peningkatan mekanisme pemompaan obat keluar sel (efflux) (Niel, 2006).

\section{Simpulan Dan Saran}

Rhinosinusitis adalah peradangan simtomatis pada sinus paranasales dan cavum nasi. Bakteri yang paling sering menyebabkan rhinosinusitis yaitu bakteri Staphylococcus aureus, Staphylococcus epidermidis, Eschirechia coli, Bacillus sp. Hasil uji kepekaan antibiotic menunjukkan bahwa bakteri Staphylococcus aureus memiliki tingkat sensitivitas yang sama terhadap keempat antibiotik yakni sefuroksim, sefiksim, siprofloksasim dan klindamisin. Sedangkan bakteri Staphylococcus epidermidis memperlihatkan tingkat sensitivitas yang sangat tinggi terhadap antibiotik sefuroksim dan 
klindamisin. Bakteri Eschirechia coli menunjukkan tingkat sensitivitas paling tinggi terhadap antibiotik amoksisilin klavulanat dan sefiksim dan sama sekali tidak menunjukkan sensitivitas terhadap ketiga antibiotik lainnya yakni sefuroksim, siprofloksasin dan klindamisin. Bakteri Bacillus sp. menunjukkan tingkat sensitivitas paling tinggi terhadap sefuroksim, siprofloksasin dan klindamisin dan sama sekali tidak menunjukkan sensitivitas pada kedua antibiotik lainnya yakni amoksisilin klavulanat dan sefiksim. Maka dari itu dalam memberikan tatalaksana medikamentosa pada kasus rhinosinusitis sebaiknya antibiotic diberikan secara rasional dan diberikan sesuai dengan bakteri penyebabnya untuk mencegah resistensi antibiotik.

\section{Daftar Rujukan}

Araujo E., Dall C., C. V, \& Pereira A., \& M. A. (2017). Microbiology of middle meatus in chronic rhinosinusitis. Brazilian J Otorhinolaryngology.

Boase S., et all. (2013). The microbiome of chronic rhinosinusitis: culture, molecular diagnostics and biofilm detection. BMC Infectious Disease.

Bubun J., Azis A., Akil A., \& P., \& F. (2009). Hubungan gejala dan tanda rinosinusitis kronik dengan gambaran CT-Scan berdasarkan skor Lund-Mackay. (Bagian ilmu kesehatan THT, Ed.). Makassar: Fakultas Kedokteran Universitas Hasanudin.

Deshpande JD., \& J. M. (2011). Antimicrobial Resistance: The Global Public Health Challenge. International Journal of Student Research, 1(2). Retrieved from http://www.ijsronline.com/temp/IntJS tudRes1241-5614199_153541.pdf

Dlugaszewska J., L. M., Lenkowski M., T. A., \& Pastusiak T., \& S. W. (2016). The pathophysiological role of bacterial biofilms in chronic sinusitis. Poland: Eur Arch Otorhinolaryngol,. https://doi.org/10.1007/s00405-015-3650-5

Fauzi., Sudiro M., \& L. B. (2015). Prevalence of allergic rhinitis based on world health organization (ARIA - WHO) questionnaire among batch 2010 students of the faculty of medicine universitas padjajaran. Althea Medical Journal, 2(4).

Fokkens, W. J., et all. (2012). EPOS 2012: European Position Paper On Rhinosinusitis And Nasal Polyps 2012. A Summary for Otorhinolaryngologists, 50(1). https://doi.org/doi.org/10.4193/Rhino50E2

Harahap NIK., Siregar SM., \& N. M. (2018). Profil Kuman Pada Sekret Hidung Penderita Rinosinusitis Kronis Di Rumah Sakit Haji Medan. Ibnusina Biomedika, 2(1).

Ketut Surya, N. (2014). Analisis Implementasi Kebijakan Penggunaan Antibiotik Rasional Untuk Mencegah Resistensi Antibiotika di RSUP Sanglah Denpasar: Studi Kasus Infeksi Methicillin Resistant Staphilococus Aureus. Jurnal Administrasi Rumah Sakit Indonesia, 1(1).

Mangunkusumo E., \& S. D. (2016). Buku ajar ilmu kesehatan telinga hidung tenggorok kepala dan leher. (R. R. Soepardi EA, Iskandar N, Basruddin J, Ed.), Jakarta: Balai Penerbit FK UI (7th ed., Vol. 106).

Massoth, L., Anderson, C., \& McKinney, K. A. (2019). Asthma and Chronic Rhinosinusitis: Diagnosis and Medical Management. Medical Sciences, 7(4). https://doi.org/doi.org/10.3390/medsci7040053

Niel, M. (2006). Medical Pharmacology At a Glance (5th ed.). Jakarta: Erlangga.

Poanchanukoon 0. (2012). Pediatric acute and chronic rhinosinusitis: comparison of 
clinical characteristics and outcome of treatment. Asian Pacific J Allergy Immunol, $30(2)$.

Putra NP. (2015). Perbedaan Jenis Bakteri di Cavum Nasi dengan di Sinus Maksila pada Pasien Rhinosinusitis Maksilaris Kronis : Tesis. Jogjakarta: Universitas Gajah Mada.

Rosenfeld., et all. (2015). Clinical Practice Guideline (Update): Adult Sinusitis. Otolaryngology-Head and Neck Surgery, 152(52).

Saputra A., Qamariah N., \& M. N. (2016). Pola Kepekaan Isolat Bakteri Aerob Pada Rhinosinusitis Kronis. Berkala Kedokteran, 13(1).

Tiara Y., Alwi M., \& G. M. (2014). Identifikasi bakteri flora normal mukosa hidung dan saliva pada penambang emas (tromol) di Kelurahan Poboya Kecamatan Palu Timur Sulawesi Tengah. Palu: J Biocelebes, 8(1).

Y Nurmalasari. (2017). Faktor-Faktor Prognostik Kesembuhan Penobatan Medikamentosa Rinosinusitis Kronik Di Poli THT RSUD A. Dadi Tjokrodipo Bandar Lampung Tahun 2017. Jurnal Ilmu Kedokteran Dan Kesehatan, 4(3).

Yama D, P. K., Setiawan, E. P., \& Sutanegara, S. W. D. (2018). Karakteristik Penderita Rinosinusitis Kronik yang Rawat Jalan di Poli THT-KL RSUP Sanglah Denpasar Tahun 2016. E-Jurnal Medika Udayana, 7(12).

Zhang Y., et all. (2017). Chronic rhinosinusitis in Asia. Journal of Allergy and Clinical Immunology, 140(5). 